\title{
A NÖVŐTÉR-SZABÁLYOZÁS HATÁSA FÁS SZÁRÚ NEMESNYÁR ÜLTETVÉNY DENDROMASSZA-HOZAMÁRA
}

\author{
Heilig Dávid, Heil Bálint és Kovács Gábor \\ Soproni Egyetem, Erdőmérnöki Kar, Környezet- és Földtudományi Intézet
}

\begin{abstract}
Kivonat
Napjainkban egyre nagyobb szerepet kap a faanyagtermelésben az ültetvényes fagazdálkodás. Nő a rövid vágásfordulós és midirotációs ültetvények területe Európában, viszont kevés információ áll rendelkezésünkre arról, hogy a hagyományos erdészeti beavatkozások, mint például a szisztematikus gyérités az ültetvény első éveiben milyen hatást gyakorol a hozamra. Kutatásunk során arra kerestünk választ, hogy növőtér-szabályozással növelhetö-e a midirotációs nemesnyár ültetvények hozama. A Dejtár 4 CS erdőrészlet területén 2011-ben létesített kísérleti ültetvényen vizsgáltuk, hogy az 'AF2' klón esetében az azonos erélyü, de eltérő korban végrehajtott beavatkozás hogyan befolyásolja a dendromassza-hozamok alakulását, dendrometriai mérések és modellezés segítségével 6 vegetációs időszakon keresztül. A teljes dendromassza tekintetében nincs különbség a kontroll és a bővített növőterű parcellák között, sem az eltérő időpontban végzett beavatkozások között a vizsgált időszak során. A növőtér-szabályozást követően az előző év növedékénél és a kontroll parcellák növekedéséhez képest is nagyobb volt a hozam a növőtér-szabályozott parcellák esetében. Bár a dendromassza-készlet tekintetében közel azonosak, de a különbözö növőterü fák dimenziói között határozott eltérés mutatkozik, ezáltal a növőtérszabályozás a termelni kívánt választék minőségére gyakorol hatást.
\end{abstract}

Kulcsszavak: rövid vágásfordulós ültetvény, növőtér, hozambecslés

\section{EFFECTS OF SPACING CONTROL ON DENDROMASS YIELD IN SHORT ROTATION HYBRID POPLAR PLANTATION}

\begin{abstract}
Nowadays forest plantations have a growing role in wood production. The area of SRF plantations is growing in Europe, but there is only little information about how traditional forestry interventions, like thinning affects yield in the first couple of years after establishment on short and midi rotation plantations. The aim of this paper is to see if spacing controls result in higher yields. In 2011 an experimental plantation was established in the Dejtár 4 CS forest compartment, where the same intensity spacing control was used but at a different age on 'AF2 to see how it affects the yield. For this purpose, dendrometrical measurements were completed for 6 continuous growing seasons. There is no difference in the aspect of dendromass inventory between the controlled and not controlled plots nor in the case of interventions at different ages during the examination period. Following the year of spacing control, increment was higher than in the last growing season and then in the control plots. Despite having no difference between the yields, the dimensions of trees show difference in spacing controlled plots and in the control ones. This means that the spacing control mostly affects the quality of wood.
\end{abstract}

Keywords: short rotation forestry, spacing, yield estimation 


\section{BEVEZETÉS}

A21. század elején egyre növekvő igény mutatkozik a faanyagra Európa szerte. Az energetikai felhasználás mellett az ipari alapanyagként szolgáló fatermékek termelése is növekedik. Egyre nagyobb az erdők területfoglalása, illetve növekedik a kitermelhető famennyiség is és ezzel együtt emelkedik az intenzív ültetvényes fagazdálkodás aránya is.

Várhatóan Közép-Európában a legnagyobb arányban hasznosított megújuló energiaforrás a szilárd biomassza lesz, amihez célszerủ lenne egy helyi nyersanyagelláású, kis kapacitású biomassza erőműhálózat létrehozása, mely alkalmas lenne helyi energiaigények kiszolgálására (Fischer et al 2010).

A fás szárú ültetvényekben elsősorban olyan pionír fajokat, illetve ezekből nemesített fajtákat alkalmaznak, melyek a gyenge termőhelyi adottságok mellett is rövid idő alatt - 5-8 éves rotációval - megfelelö minőségü és mennyiségü faanyagot szolgáltatnak ott, ahol a hagyományos erdőgazdálkodás, de még a mezőgazdasági müvelés sem feltétlenül gazdaságos (Kovács et al 2013).

Hazánkban és a közép-európai térségben egyaránt növekedik az igény és a kedv rövidvágásfordulós ún. midirotációs iparicélú ültetvények létrehozására. Ezen ültetvények célja, hogy ipari felhasználásra alkalmas faanyagot termeljen (10-14 cm mellmagassági átmérő 5-10 éves vágásfordulóval). Így szükséges a vizsgált térségben is olyan kutatások elvégzése, melyek a Közép-európai térség termőhelyi adottságaihoz illeszkednek.

Alapvetően meghatározza a hozamokat a klíma, hidrológia és a talaj. Az ültetvényeknél még jelentős szereppel bír a feltalaj tápanyag készlete és a vízgazdálkodása, ugyanis a telepítést követő első két évben a sekély gyökérzettel rendelkezö fajták elsősorban a felső rétegekböl veszik fel a növekedésükhöz szükséges tápanyagokat, illetve vizet. Ahhoz, hogy gazdaságilag versenyképesek legyenek az ültetvények más mezőgazdasági kultúrákkal szemben, legalább 8-10 (abszolút száraz tonna) atro tlév/ha hozamot kell elérniük (Murach et al 2009).

A kialakított ültetvényen lehetőség nyilik mind az energetikai célú faanyagtermelés, mind az ipari célú választékok termelésének vizsgálatára. Az eredményeket atro t/ha dimenzióban határoztuk meg, ami alkalmas energetikai és ipari célú választékok mérésére is. A teljes dendromassza-hozam a dolgozatunk esetében a vágáslap feletti összes fatermés változását, éves átlagos növedékét jelenti leszámítva az elöhasználat során kitermelt fatömeget.

Cikkünkben a Dejtár 4 CS erdőrészlet területén létesített kísérleti ültetvényen végzett növőtér-szabályozás eredményeit mutatjuk be. Egy adott telepítési hálózatban az eltérő korban történő azonos erélyü beavatkozás milyen hatást gyakorol a dendromassza-hozam mennyiségére és minőségére. Azért tartjuk különös jelentőségünek eredményeink közlését, mivel hasonló jellegủ publikációt a szakirodalomban nem találtunk.

\section{ANYAG ÉS MÓDSZER}

\section{Kísérleti terület bemutatása}

2011 májusában egy 5 ha területủ 60 parcellás kísérleti ültetvény (1. ábra) alakítottunk ki a Dejtár 4 CS erdőrészlet területén. A kísérleti terület kialakítása során a hazánkban leggyakoribb nemesnyárfajtákat alkalmaztuk vagy 2 m-es karódugvánnyal ('AF2'), vagy 30 cm-es dugvánnyal ('AF2', 'Monviso', 'Pannonia'). Vágvölgyi (2013) szerint Magyarországon a legnagyobb hozamot a nyár klónok, ezek közül is az 'AF2' és a 'Monviso' adják. 15 parcellás csoportokként eltérő tápanyagutánpótlás történt. Ezen túl a karódugványos parcellákban növőtér-szabályozást is végeztünk. A telepítési hálózat $3 \times 1$ m-es. Egy parcella 12 sort, soronként 22 egyedet tartalmaz. 
A kísérleti ültetvény Cserhát-vidék erdészeti tájban, azon belül az Ipoly-medence tájrészletben fekszik. A makroklíma mérsékelten hűvös - mérsékelten száraz. Az évi középhőmérséklet $9,6{ }^{\circ} \mathrm{C}$, a tenyészidőszaki $16,3^{\circ} \mathrm{C}$ Az átlagos csapadékösszeg $567 \mathrm{~mm}$, míg a vegetációs időszakban 338 mm hullik. Az évi csapadékés hőmérsékletjárás alapján a klíma egyfajta átmenet az erdőssztyepp és a zárt tölgyes klíma között (Halász 2006).

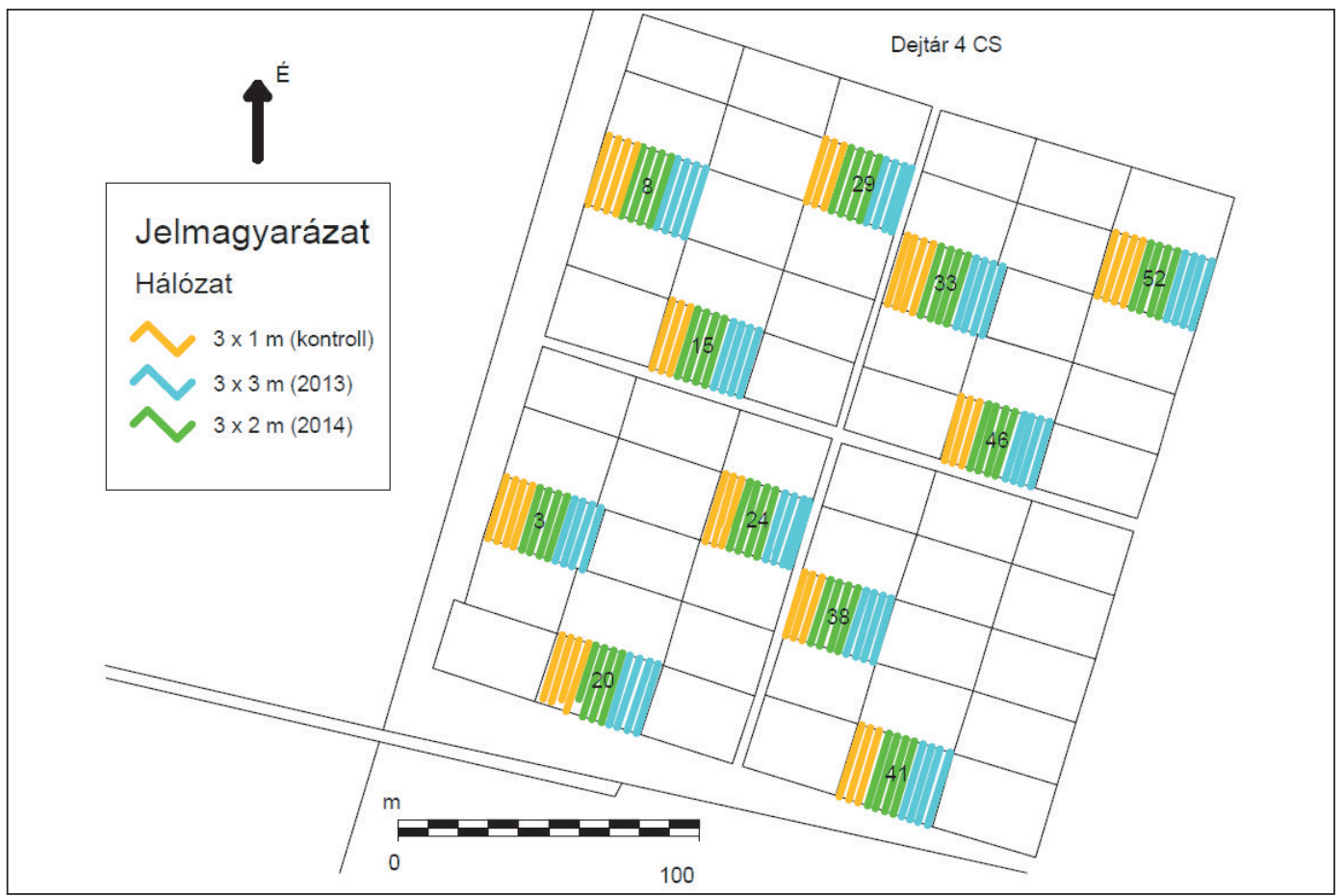

1. ábra: Kísérleti ültetvény elrendezése, kiemelve a növőtér-szabályozás által érintett sorokat (Szente 2016)

Figure 1: Experimental design with the spacing controlled rows highlighted (Szente 2016)

A terület 150 m tengerszint feletti magasságú, sík fekvésü, erdészeti klímaosztálya kocsánytalan tölgyes ill. cseres klíma, időszakos vízhatású kovárványos barna erdőtalajú homok fizikai talajféleséggel és mély termőréteggel (Szabó 2016). Ezen termőhelytípusváltozat megfelel az ültetvényes nemesnyárgazdálkodás igényeinek is.

\section{Növőtér-szabályozás és felvételezés módja}

Jelen vizsgálat tárgyát három karódugvánnyal telepített parcella $(3,20,24)$ képezi, melyek termőhelyi paraméterei azonosak, továbbá egyező tápanyagutánpótláson estek át (40 t/ha szervestrágya). Minden parcella (12 sor) 4 soronként alparcellákra lett bontva. Nyugatról keletre haladva az első alparcellán nem végeztünk növőtér-szabályozást (kontroll), a második alparcellán (2014-es jelű sorok) a harmadik vegetációs időszakot követően bővítettük a növőteret 3 m²-ről 6 m²-re, amivel a hektáronkénti törzsszám 3330-ról 1665re csökkent. A harmadik alparcellán (2013-es jelü sorok) a második vegetációs időszakban történt az előzővel azonos erélyü beavatkozás (Terjéki 2014). A sematikus gyérítés párhuzamos rendszerben valósult meg, azaz a páros sorszámú egyedeket vágták ki. 
Az egyedszámok változását vizsgáltuk a kezdeti, illetve a növőtér-szabályozást követő egyedszámokhoz viszonyítva, ezzel bemutatva az eltérő növőterű parcellákon bekövetkező természetes mortalitást.

A vizsgált parcellákon az egyedek mellmagassági kerületét megmértük mm-es beosztású szalaggal. Továbbá a növőtér-szabályozás során kivágott fák magasságát is meghatároztuk dm-es pontossággal mérőszalag segítségével, a további években - mikor már nem történt kitermelés - soronként egy átlagfa magasságát mértük meg Haglöf ECll elektronikus famagasság és lejfokmérő segítségével. Az első év végén elvégzett dendrometriai méréseket a kis mellmagassági kerület értékek és a parcellák közötti minimális magasságkülönbség okán nem vettük figyelembe a számítások során. A telepítést követően a második vegetációs időszaktól kezdve minden vegetációs időszak befejeztével dendrometriai méréseket végeztünk. A 6. vegetációs időszakot követően egy fa került kivágásra, majd az abból vett mintákból a nedvességtartalom és a sürüség értékét határoztuk meg.

A mért mellmagassági kerület átmérőre történő átszámításánál kör keresztmetszetet feltételeztünk. Vizsgáltuk, hogy vegetációs időszakonként hogyan változik az átmérőnövekedés, illetve erre milyen hatást gyakorol a növőtér-szabályozás.

A mért átmérők és magasságok segítségével logaritmikus famagasság görbét szerkesztettünk. Ez alapján elemeztük a magasság beavatkozások szerinti változását, továbbá ezt használtuk fel az fatérfogatok meghatározásánál. Az egyes fák térfogatának számításához a Király László-féle kétváltozós fatérfogat-függvényt alkalmaztuk. A próbafás módszer során az állomány egyedszámát kell meghatározni, majd mintafákat kiválasztva - célszerüen átlagfák - a mintatestek száraz tömegét és a faegyed magasságát és tő- vagy mellmagassági átmérőjét megmérni. Az átlagfák térfogata meghatározható az átmérő és magasság függvényében, a mintatest térfogatát megmérve és ezzel az értékkel osztva a mintatest tömegét az átlagfára jellemző sűrűség számítható. A sürüség és a faegyed térfogata adja a fa teljes tömegét, aminek az egyedszámmal vett szorzata adja a teljes állomány száraz tömegét (Halupa 2008).

$$
v=\left(p_{1}+p_{2} \cdot d \cdot h+p_{3} \cdot d+p_{4} \cdot h\right) \cdot\left(\frac{h}{h-1,3}\right)^{k} \cdot\left(\frac{d^{2} \cdot h}{10^{8}}\right)
$$

ahol:

$\begin{array}{ll}v & : \text { az adott fa vágáslap feletti összes térfogata }\left(\mathrm{m}^{3}\right), \\ \mathrm{d} & : \text { mellmagassági átmérő }(\mathrm{cm}), \\ \mathrm{h} & : \text { famagasság }(\mathrm{m}) \\ \mathrm{p}_{1}, \mathrm{p}_{2}, \mathrm{p}_{3}, \mathrm{p}_{4} & : \text { : paraméterek, } \\ \mathrm{k} & : \text { kitevő. }\end{array}$

A számításokhoz az 'Olasznyár'-ra vonatkozó paramétereket használtuk ( $k=4, p_{1}=2341,13687$, $p_{2}=-0,13816, p_{3}=14,43934, p_{4}=15,62451$ ) (Sopp 2000). Mivel a függvény az alacsony fák térfogatát torzítja, így - Veperdi Gábor javaslatára - az alábbi módosítást alkalmaztuk:

ha $\mathrm{h} \leq 2,0 \mathrm{~m}$, akkor $\mathrm{v}=0,003 \mathrm{~m}^{3}$,

ha $\mathrm{h} \leq 3,0 \mathrm{~m}$, akkor $\mathrm{v}=0,005 \mathrm{~m}^{3}$.

Az így nyert térfogat értékeket az általunk meghatározott a sürüséggel szorozva, majd a nedvességtartalommal redukálva atro tonnára számítottuk. A kapott tömegeket parcellánként és beavatkozások szerint csoportosítva összegzésre kerültek, majd a terület ismeretében hektárra vetítettük az összehasonlíthatóság végett. A hozamok megállapításánál az egymást követő évek készleteinek különbségét vettük, kivéve a növőtér-szabályozást követő évben. Ekkor az előző év készlete felének és az adott év készletének különbségeként értelmeztük a hozamot. 


\section{Statisztikai számítások és szoftverek}

Az átlagátmérő meghatározásánál négyzetes középértéket és átlag magasság számítása során - az erdészeti gyakorlatnak megfelelően - a körlappal súlyozott átlagértéket határoztuk meg (Veperdi 2011).

A számítások a Microsoft ${ }^{\circledR}$ Excel 365 és a STATISTICA programcsomag 12-es verziójával készültek.

Az eloszlásvizsgálat során normál-eloszlást feltételeztünk. A próba elvégzéséhez az osztályok számát Sturges (1926) által javasolt formula szerint számítottuk. A nullhipotézist elfogadjuk, azaz az eloszlást normálisnak tekintjük, ha az empirikus szignifikancia szint (p) meghaladja a 0,05-os értéket.

\section{EREDMÉNYEK ÉS MEGVITATÁSUK}

\section{Átlagátmérő alakulása a vizsgálati időszakban}

A második vegetációs időszakot követő méréseink szerint az állomány egységes, az átlagos átmérő az ültetvényen 4,3 cm. A 2. ábrán látható, hogy a kontroll parcellák átlagátmérője lassuló ütemben növekedik. Az utolsó két évben a növekedés szinte azonos mértékü. Az átlagátmérő éves folyónövedéke 1,6 cm/év. A 2013-as vegetációs időszaktól kezdődően bővített növőterű parcellák a harmadik vegetációs időszakban a legnagyobb átmérő folyónövedéket $(3,1 \mathrm{~cm} / e ́ v)$ érték el, a megnövekedett növőtér hatására. Az ezt követő években a növekedési üteme - hasonlóan a kontroll parcellákéhoz - lassul. A 2014-es jelü parcellák növőtérszabályozása a 2014-es vegetációs időszak előtt történt, aminek eredményeképpen ezen évben a legnagyobb átmérőgyarapodást mutatta, ami még az előző évi értéket is meghaladta. Ezen esetben a növőtér-szabályozás bizonyosan igen kedvező hatású, hiszen a fajtára jellemző éves átmérőgyarapodási tendenciához képest magasabb értéket jelent. A következő évek során a másik két kezeléséhez hasonló mértékben csökken az átlagátmérő folyónövedéke ebben az esetben.

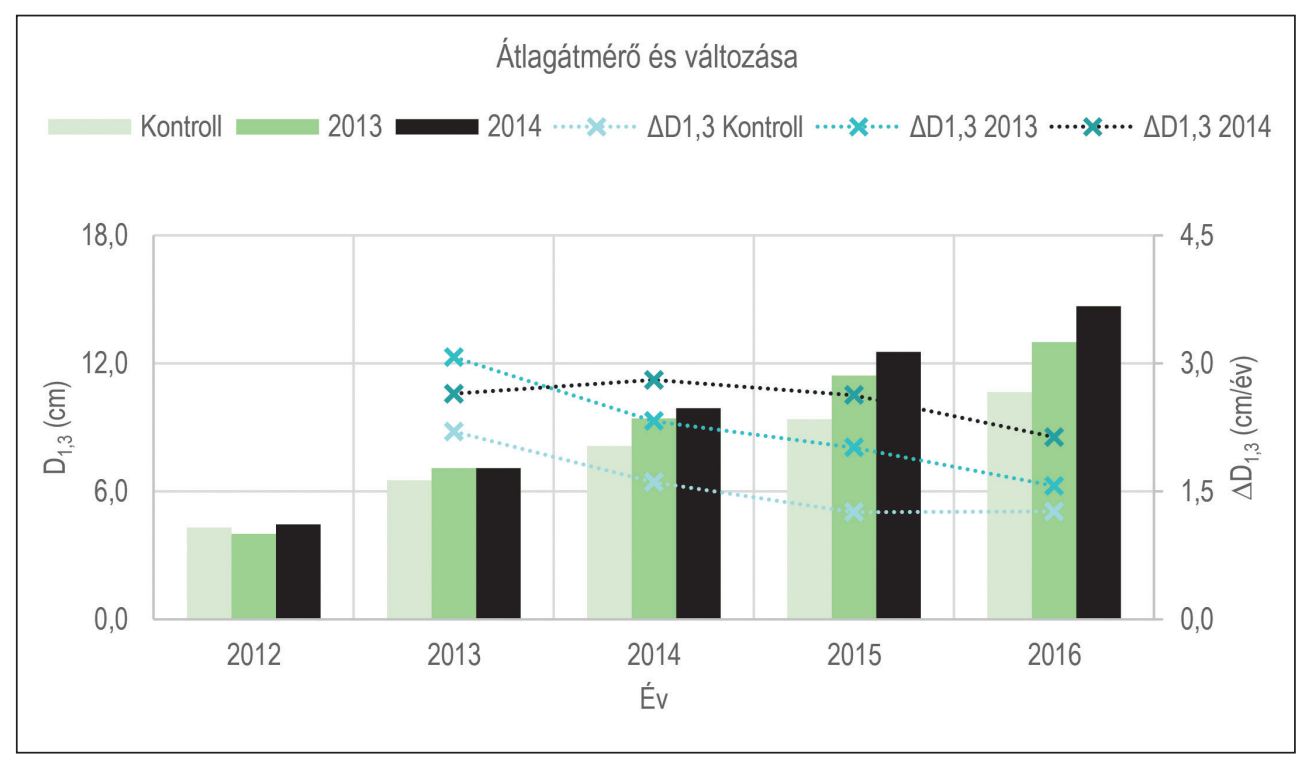

2. ábra: Átlagátmérők és növekedésük kezelésenként csoportositva

Figure 2: Average and growth of diameters grouped by the year of spacing control 
A növőtér-szabályozás hatással van az átlagátmérő változására. A második vegetációs időszak után végrehajtott beavatkozás is eredményes, de kimagasló értéket a harmadik vegetációs időszakot követő gyérítés alkalmával tapasztaltunk. Ennek oka feltehetően, hogy a második év végén az állomány még nem teljesen záródott, azaz a fák a rendelkezésre álló teret még nem teljesen használják ki, míg a 3,0 m²-es növőteret a 2014-es parcellák esetében a harmadik vegetációs időszak végére teljesen kihasználták és így a gyérítés hatására "közvetlenül hasznositható növőtérre” tettek szert. Ezt támasztja alá a kontrollparcellákhoz képest magasabb átmérögyarapodás a kezeltek esetében.

\section{Hozamok alakulása a vizsgálati időszakban}

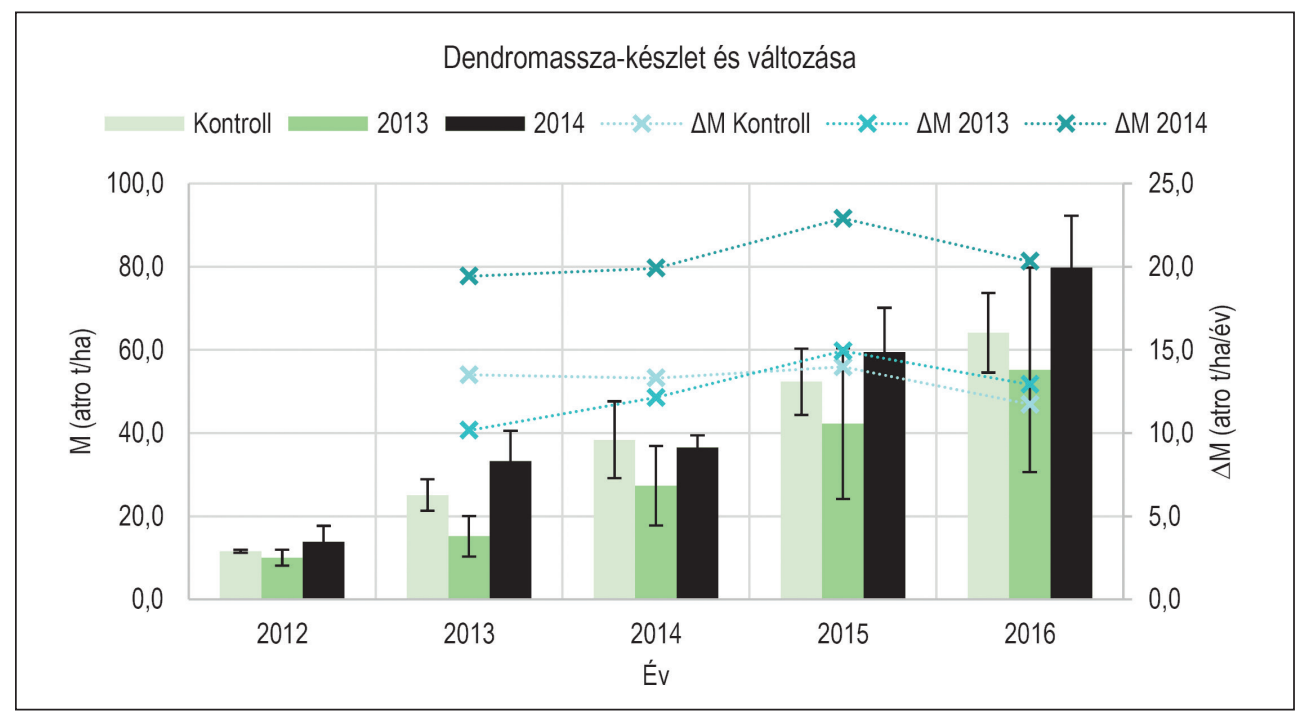

3. ábra: Száraz dendromassza-készlet és változása kezelésenként csoportosítva

Figure 3: Average and change of dry dendromass grouped by spacing control

A 3. ábrán látható a dendromassza-készlet és változása, feltüntetve a kezelésekbe eső parcellák közötti szórást is. A második vegetációs időszak végén - 2012-ben - a kezelések dendromassza mennyiségében nem mutatkozik nagyobb eltérés. A következő évben a növőtér-szabályozott, 2013-as jelü parcellák átlagos dendromassza-készlete elmarad a két, eddig kezeletlen parcella dendromassza mennyiségéhez képest. Ennek oka, hogy a növőtér-szabályozás során a beavatkozásig keletkezett dendromassza felét (5,0 atro t/ha) kitermelték. A másik két kezelés parcelláinak növedéke nem változott a 2013-as és 2014-es években jelentősen. A 2014-es jelủ parcellák növőtér-szabályozásakor 16,6 atro t/ha-t termeltek ki. Az előhasználatok során kitermelt fatérfogat további felhasználásra nem került, így az összes fatermés számításában sem jelenik meg, bár üzemi léptékben célszerü lenne ezt a faanyagot is felhasználni. A megnövelt növőteret jól tudták hasznosítani a parcellák ültetvényei, így kimagasló növedék értéket kaptunk. A kontroll parcellák növedéke nagyjából állandó értéket mutat a vizsgált időszakban.

A 2016-os év előző évekhez képest elmaradó növedék értéke feltehetően a kedvezőtlen időjárásnak tudható be. Hőmérséklet szempontjából az év kiegyensúlyozottnak mondható a nevezett év, de az átlagosnál több csapadék hullott, de ezek gyakran - föként a nyári záporok - rövid idő alatt hoztak jelentős vízmennyiséget, ami képtelen volt a talajba szivárogni (Kolláth et al 2017). 


\section{Az utolsó vizsgált vegetációs időszak egyesfa száraztömeg-eloszlásai}

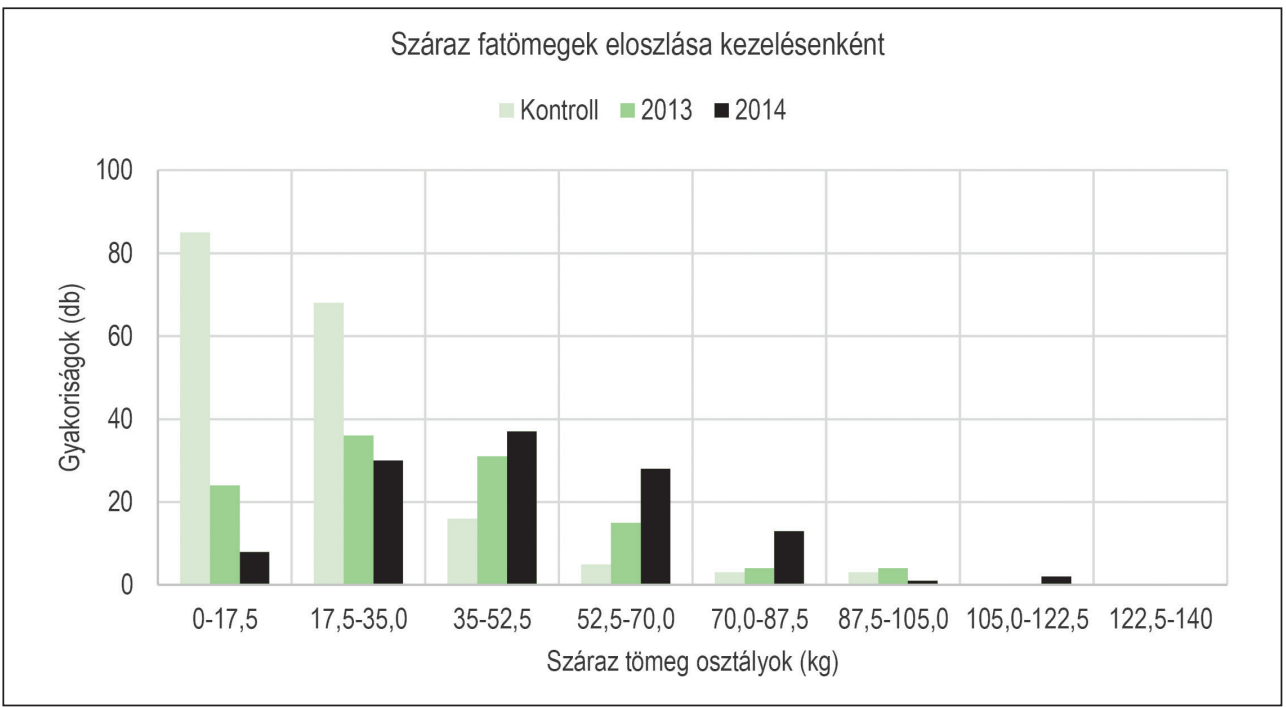

4. ábra: Száraz fatömegek eloszlása kezelésenként

Figure 4: Distribution of dry dendromass grouped by year of spacing control

$A z$ 4. ábrán az egyes fák száraz tömegének eloszlása látható. A teljes tömegeloszlást 8 csoportra osztottuk. Majd vizsgáltuk, hogy a különböző kezelések követik-e a normális eloszlást. Ez a két kezelt parcella esetében teljesül, míg a kontroll parcellák esetében nem (1. táblázat). A kontroll parcellák egyedeinek közel fele (85 db) esik az első osztályba, míg az alsó két osztályba az egyedek 85\%-a esik (153 db). A magasabb tömegü osztályokba azon egyedek esnek, melyek növőtere a tervezettnél nagyobb, mivel az elpusztult egyedekkel szomszédosak, illetve a 8-as parcella nyugati szélén találhatók, így erős szegélyhatás érvényesül.

A tömegeloszlás tekintetében t-próbát végeztünk, hogy megvizsgáljuk, hogy az eltérő időpontban végzett kezelések hatással vannak-e az átlagfa száraztömegére. F-próba igazolta a varianciák egyezőségét, így teljesül a t-próba előfeltétele $(p=0,56)$. A két kezelés nem tér el szignifikánsan egymástól $(p=0,06)$, tehát a 2013-as és 2014-es jelü parcellák fáinak átlagos tömege egyezik. A beavatkozások között eltelt egy vegetációs időszak nem eredményez kimutatható különbséget az egyesfa tömegek eloszlásában.

1. táblázat: Fák száraz tömegének eloszlásvizsgálata kezelésenként csoportositva

Table 1: Distribution fitting of dry dendromass of individual trees grouped by year of spacing control

\begin{tabular}{|c|c|c|c|}
\hline Beavatkozás & $\mathbf{X}^{2}$ & Szabadsági fok & $\mathbf{p}$ \\
\hline Kontroll & 17,30008 & 1 & 0,00003 \\
\hline 2013 & 1,75915 & 2 & 0,41496 \\
\hline 2014 & 1,73014 & 2 & 0,42102 \\
\hline
\end{tabular}

\section{Az utolsó vizsgált vegetációs időszak eredményei}

A 2. táblázatban találhatók a 6 . vegetációs időszakot követő mérések eredményei. A kezdeti tőszámhoz képest a kontroll parcellák mutatták a legalacsonyabb tőszámot. Itt a fák mindössze 81\%-a maradt életben. 
Feltehetően ez egy öngyérülési folyamat, ami a növőtér beszükülése és az állomány differenciálódása következtében jön létre. A kezelt parcellák esetében a viszonyítási alapot a növőtér-szabályozást követő tőszám jelenti. Ezen két csoport esetében a túlélés magas értéket mutat. A kontroll parcellák magas pusztulási arányából azon következtetés vonható le, hogy a kezdet $3 \times 1$ m-es növőtér 6 vegetációs időszak végére, már kicsinek bizonyul.

2. táblázat: A vizsgálat eredményei 2016-ban kezelésenként csoportositva

Table: 2: Results in 2016, grouped by year of spacing control

\begin{tabular}{|c|c|c|c|c|c|c|}
\hline \multirow{3}{*}{ KBeavatkozás } & \multirow{3}{*}{$\begin{array}{c}\text { Elemszám } \\
(\mathrm{db}) \\
\end{array}$} & \multirow{3}{*}{$\begin{array}{c}\text { Túlélés } \\
(\%) \\
\end{array}$} & Mellma & gi átmérő & \multirow{3}{*}{$\begin{array}{c}\text { Dendromassza } \\
\text { (atro t/ha) } \\
\end{array}$} & \multirow{3}{*}{$\begin{array}{c}\text { Folyónövedék átlaga } \\
\text { (atro t/ha/év) }\end{array}$} \\
\hline & & & $\overline{\mathbf{x}}$ & $\sigma$ & & \\
\hline & & & \multicolumn{2}{|c|}{$(\mathrm{cm})$} & & \\
\hline Kontroll & 180 & $81 \%$ & 10,6 & 3,6163 & 64,1 & 13,1 \\
\hline 2013 & 114 & $95 \%$ & 13,0 & 3,3811 & 55,2 & 12,5 \\
\hline 2014 & 119 & $92 \%$ & 14,7 & 4,0431 & 79,8 & 20,6 \\
\hline
\end{tabular}

A kontroll parcellák esetében a sűrü állomány következtében az átlagos átmérő elmarad a nagyobb növőterű parcellákhoz képest. Ezen értékek szórása hasonlóan alakul a kezelések között. A mellmagassági átmérő szórása a legmagasabb a 2014-es jelü parcellák esetében, amit a kontroll parcellák szórása követ. Ez feltehetően az elpusztult egyedek környezetében található egyedek többlet növőtere okozta.

Legnagyobb dendromassza a 2014-es jelü parcellák esetében keletkezett, ezt a kontroll parcellák követték. Ennek oka, hogy bár dimenzióiban alulmarad a 2013-as jelü parcellákhoz képest, de egyedszámában közel másfélszerese annak. Hozamok viszonylatában a kontroll és a 2013-as jelű parcellák közel azonos korszaki átlagot mutatnak ( 13 atro t/ha/év). Ezt jelentősen meghaladja a 2014-es jelü parcellák 20 atro t/ha/ év-es korszaki átlagos növedéke. Összességében ezek mindegyike meghaladja a gazdaságossági küszöb (8-10 atro t/ha/év) értékét.

\section{ÖSSZEFOGLALÁS}

Kutatásunk célja, hogy feltárjuk milyen hatást gyakorol az eltérő korban végrehajtott, azonos erélyü növőtér-szabályozás rövid vágásfordulós nemesnyár ültetvények dendromassza-hozamában. A kísérlet végén arra a következtetésre jutottunk, hogy a lábon álló dendromassza tekintetében különbség mutatkozik az eltérő korban végzett növőtér-szabályozások között. A 6. vegetációs időszak végén a kontroll parcellák átlagos készlete 9 atro t/ha-ral múlja alul a 2013-as jelü parcellákét a korai beavatkozás következtében. A 2014-es jelü parcellák viszont több mint 15 atro t/ha-ral nagyobb dendromassza-készletet értek el, mint a kontroll parcellák. A 2013-es jelü parcellák előhasználata során nagyjából 5 atro t/ha fatömeget, míg a 2014-es jelű parcellákon átlagosan közel 17 atro t/ha fatömeg termeltek ki. Ezen értékeket is figyelembevéve a kontroll és a 2013as jelü parcellák eredménye dendromassza tekintetében közel azonos, míg ezeket meghaladja a 2014-es jelü parcellák készlete. Összességében a növőtér-szabályozás pozitívan befolyásolja a vizsgált ültetvény dendromassza-készletét.

Ha a beavatkozás idejének viszonylatában vizsgáljuk az eredményeket, akkor kijelenthető, hogy a második vegetációs időszak után korai végrehajtani még a növőtér-szabályozást, a harmadik vegetációs időszakot követően optimális. 
Gyakorlati szempontú következtetés, hogy ha aratógéppel történik a termelés, célszerü sürübben hagyni az állományt, hogy a tőátmérők ne haladják meg a gép befogadási tartományát. Abban az esetben, ha ipari választékot kívánunk termelni, akkor a tágabb növőtér esetében méretesebb anyagot kapunk.

\section{KÖSZÖNETNYILVÁNÍTÁS}

Köszönet illeti az Ipoly Erdő Zrt. Kelet-Cserháti Erdészetét a terület biztositásáért. A kutatás az EMMI FSA és az AGRÁRKLÍMA.2 - VKSZ_12-1-2013-0034 támogatásával valósult meg.

\section{FELHASZNÁLT IRODALOM}

Fischer G., Prieler S., van Velthuizen H., Berndes G., Faaij A., Londo M. \& de Wit M. 2010: Biofuel production potentials in Europe: Sustainable use of cultivated land and pastures. Part I: Land productivity potentials. Biomass and Bioenergy 34(2): 159-172. DOI: 10.1016/j.biombioe.2009.07.008

Halász G. 2006: Magyarország erdészeti tájai. Állami Erdészeti Szolgálat: Budapest. 70-71.

Halupa L. 2008: Energetikai faültetvények. In: Führer E., Rédei K., \& Tóth B. (eds): Ültetvényszerü fatermesztés 2. Agroinform Kiadó. Budapest. 43-55., 62-67.

Kolláth K., Csonka T. \& Bíróné Kircsi A. 2017: Beszámoló a 2016. év éghajlatáról és szélsőséges időjárási eseményeiröl. OMSZ. 27 p.

Kovács G., Heil B. \& Schmidt P. 2013: A fásszárú energiaültetvények létesitésének termőhelyi és technológiai kérdései. Elöadás. InnoLignum. Sopron

Murach D., Hartmann H., Murn Y., Schultze M., Ali W. \& Röhle H. 2009: Standortbasierte Leistungsschätzungin Agrarholzbesänden In Brandenburg und Sachsen. In: Reeg T., Bemmann A., Konold W., Murach D., \& Spiecker H. (eds): Anbau und Nutzung von Bäumen auf landwirtschaftlichen Flächen. Weinheim: WileyVHC. 181-191.

Sturges H. A. 1926: The choice of a class interval. Journal of the American Statistical Association 21: 65-66. DOI: $10.1080 / 01621459.1926 .10502161$

Sopp L. 2000: Fatömegszámítási táblázatok. Állami Erdészeti Szolgálat. Mezőgazdasági Kiadó, Budapest.

Szabó O. 2016: Természetes anyagokkal történő tápanyag-utánpótlás fás szárú energetikai ültetvényben. Doktori (PhD) értekezés. $161 \mathrm{p}$.

Szente E. 2016: Eltérő növőtér hatásának vizsgálata fás szárú energetikai ültetvény hozamára a Dejtári Csemetekertben. Diplomamunka (MSc). $62 \mathrm{p}$.

Terjéki T. 2014: Hozamvizsgálatok eltérő növőtér függvényében fás szárú energetikai ültetvényben. Diplomamunka (MSc). $96 \mathrm{p}$.

Vágvölgyi A. 2013: Fás szárú energetikai ültetvények helyzete Magyarországon napjainkig, üzemeltetésük, hasznositásuk alternatívái. Doktori (PhD) értekezés. 195 p.

Veperdi G. 2011: Erdőbecsléstan. Oktatási segédanyag. Sopron. 84 p. 